\title{
Vespa velutina: An Alien Driver of Honey Bee Colony Losses
}

\author{
Daniela Laurino *, Simone Lioy®, Luca Carisio, Aulo Manino and Marco Porporato \\ Department of Agricultural, Forest and Food Sciences, University of Turin, 10095 Grugliasco (Turin), Italy; \\ simone.lioy@unito.it (S.L.); luca.carisio@unito.it (L.C.); aulo.manino@unito.it (A.M.); \\ marco.porporato@unito.it (M.P.) \\ * Correspondence: daniela.laurino@unito.it
}

Received: 15 November 2019; Accepted: 18 December 2019; Published: 20 December 2019

\begin{abstract}
Vespa velutina, or Asian yellow-legged hornet, was accidentally introduced from China to other parts of the world: South Korea in 2003, Europe in 2004, and Japan in 2012. V. velutina represents a serious threat to native pollinators. It is known to be a fierce predator of honey bees, but can also hunt wild bees, native wasps, and other flying insects. When $V$. velutina colonies are developed, many hornets capture foraging bees which are coming back to their hives, causing an increase in homing failure and paralysis of foraging thus leading to colony collapse. The hornets may enter weak beehives to prey on brood and pillage honey. Unlike Apis cerana, Apis mellifera is unable to cope with the predation pressure of $V$. velutina. Monitoring the spread of an invasive alien species is crucial to plan appropriate management actions and activities to limit the expansion of the species. In addition, an early detection of $V$. velutina in areas far away from the expansion front allows a rapid response aimed to remove these isolated populations before the settlement of the species. Where V. velutina is now established, control measures to prevent colony losses must be implemented with an integrated pest management approach.
\end{abstract}

Keywords: Vespa velutina; alien driver; honey bee; damage; pollinator

\section{Introduction}

Invasive alien species have always been a risk to ecosystems. They are a serious obstacle to the conservation of biodiversity, both globally and locally, as their stabilization and spread in new environments break the pre-existing balances. By coming into contact with a new environment, alien species can lead to a gradual degradation and alteration of the new habitat and the decline of indigenous species, until in some cases some of them become extinct [1-3].

The Asian yellow-legged hornet (Vespa velutina nigrithorax Du Buysson) is a social wasp, belonging to one of the 11 subspecies [4-6] of V. velutina originally present in Continental Asia [7], where it is native to subtropical and temperate areas of Indo-China $[6,8]$.

The species established itself in non-native countries such as South Korea in 2003 [9] in the southern port town of Busan and Japan, on Tsushima Island in 2012 [10,11], in Kitakyushu City on Kyushu Island in 2015 [12] and on Iki Island in 2017 [13]. Arrived in France probably in 2004 along with garden pots imported from China $[14,15]$, the species spread to neighboring countries. From France it reached the Navarra province and Basque country (Spain) in 2010 [16,17], Galicia [18] and Catalunya [19] in 2012, Majorca Island (Spain) in 2015 [20,21], the Minho province (Portugal) in 2011 [22], and Flobecq in the Hainaut province (Belgium) in 2011 [23]. In 2012, the Asian yellow-legged hornet was detected for the first time in Italy in the Liguria Region [24]; afterwards the hornet started to spread in this region mainly along the coastline [25-27]. In Piedmont Region (Italy) arrived in 2013 [25,26]. It was detected also in Veneto and Lombardy Regions (Italy) between 2016 and 2017, with no more reports 
in the following years, and in Tuscany Region (Italy) in 2017. By 2017, the species had colonized an area of at least $1,110 \mathrm{~km}^{2}$ in Italy [27]. V. v. nigrithorax was firstly recorded in Germany in 2014 and a nest was found in Büchelberg (Rheinland-Pfalz) [28]. In 2016, few hornets were found in the United Kingdom, and in 2017 also in Netherland, Switzerland [29], and Scotland [30], Figure 1.

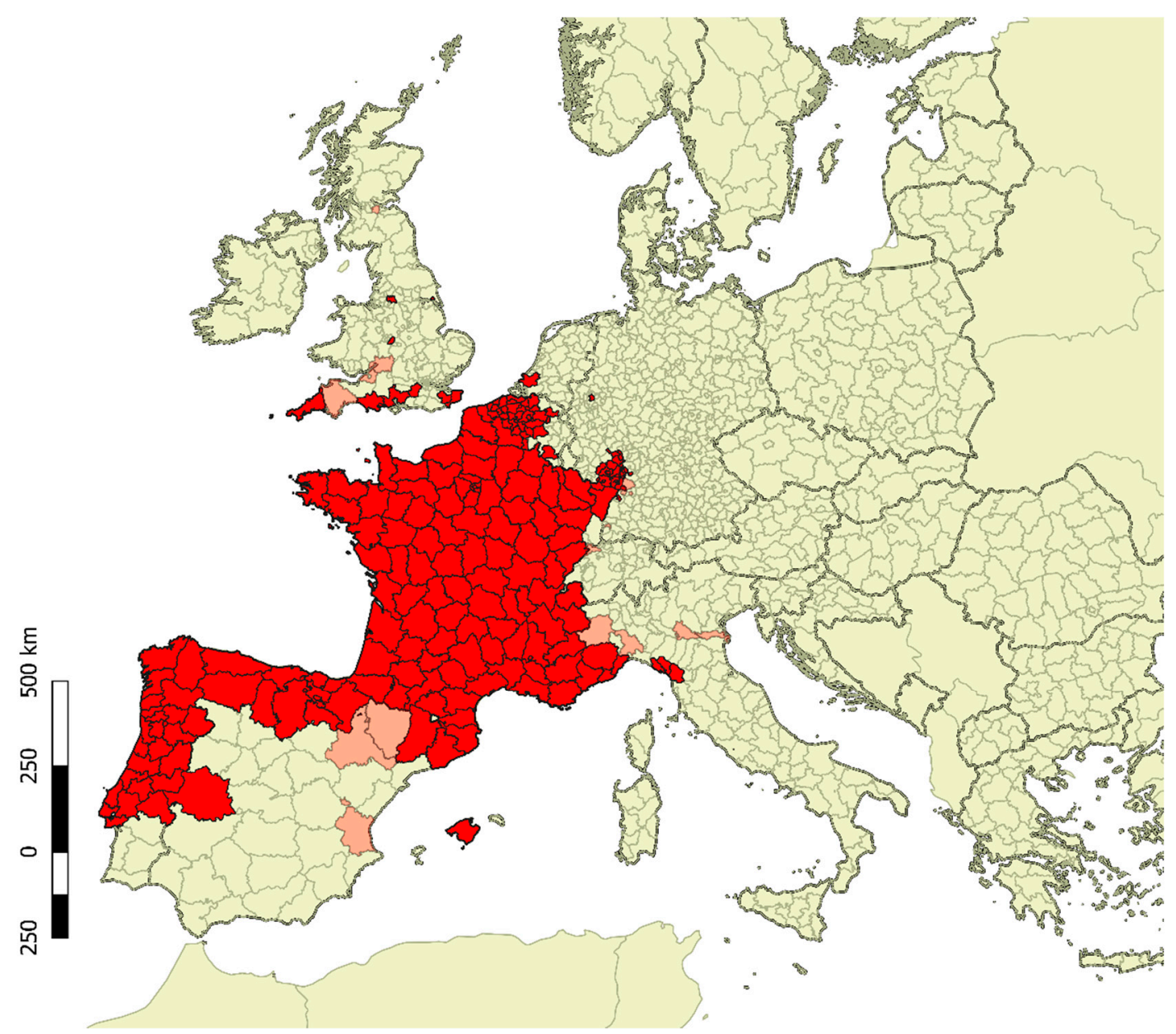

Figure 1. Presence of V. $v$ nigrithorax in Europe estimated from several sources. Red areas indicate districts where hornets are established or have been reported in 2018 and 2019. Light-red areas show districts where hornets or nests have been exclusively spotted in the past until year 2017.

The spread of $V . v$. nigrithorax in Europe and in non-native Asian regions seems to respect the predicted climatic suitability maps modelled by Villemant et al. [31]. Global warming could worsen the current situation [32]. This hypothesis was confirmed by Rodríguez-Flores et al. [18]: High minimum temperatures, dew temperature, relative humidity and low maximum temperatures favor the occurrence and spread of $V$. v. nigrithorax. These conditions are common in coastal areas and can promote the rapid dispersal of this pest.

V. v. nigrithorax creates considerable damage to the environment and beekeeping activities. For this reason, the species has been included by European Union in the black-list of invasive alien species (Reg. EU 1141/2016) for which it is mandatory to develop surveillance plans and actions to limit its spread as well as control and containment strategies. The Japanese Ministry of the Environment added this hornet to the list of invasive alien species in 2015 [33]. 


\section{Biology}

The colony of $V . v$. nigrithorax is started by a single inseminated queen that builds, using fibrous substances of plants origin and saliva, a primary nest after overwintering, typically in April, thus producing the first workers. During the warm season, they enlarge the primary nest (which has an approximate size between $4 \mathrm{~cm}$ and $15 \mathrm{~cm}$ ) directly or build a secondary nest normally on treetops [18]. Nests have normally a circular shape and can grow up to $100 \mathrm{~cm}$ in diameter, containing several thousands of hornets. Rome et al. [34] report up to 13,300 adults and 563 new queens from a single nest. At the end of the summer, reproductive individuals emerge and mate; the colonies generally collapse in late autumn or winter, while newly-mated queens search for a place where they can overwinter and, the following year, they start a new cycle [8,27,34,35], Figure 2.

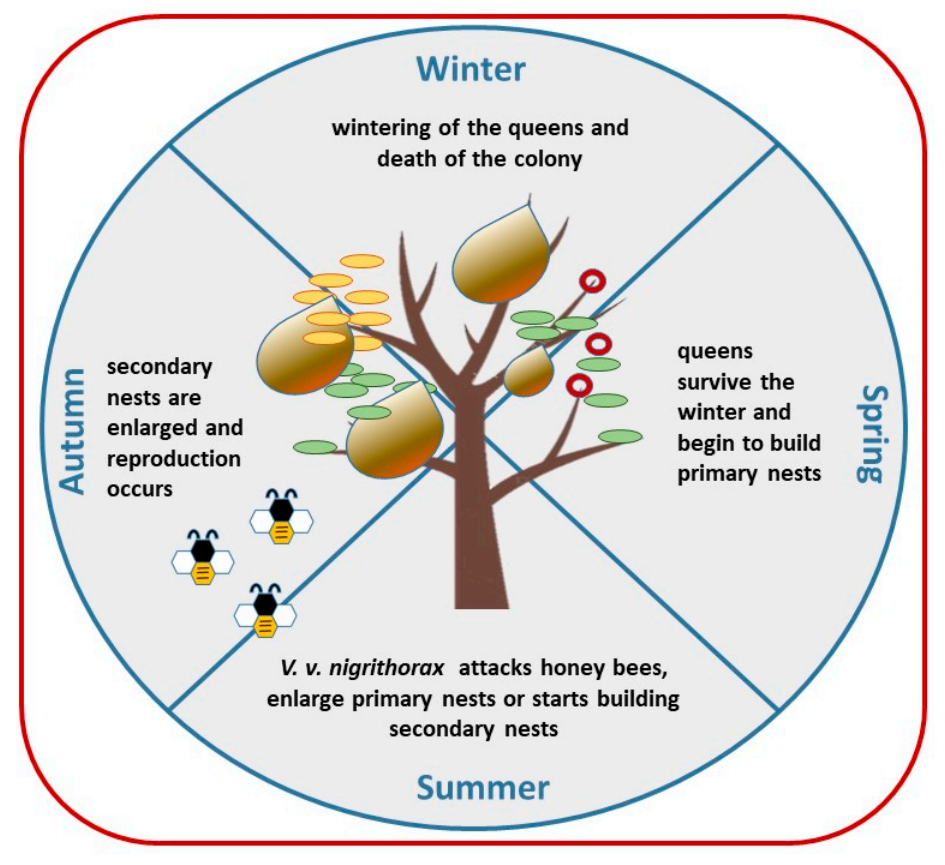

Figure 2. Life cycle of $V . v$. nigrithorax.

Hornets use olfactory stimuli to search for long-distance food sources, especially with regard to the localization of honey bee colonies, but the nature of these stimuli is not yet entirely clear [36-38].

The components of the hive, which attract the most attention of $V$. v. nigrithorax, have been the subject of study for some years. Hornets are strongly attracted by the odour of some hive products, especially pollen and honey [37]. A laboratory study showed that $V . v$. nigrithorax workers can use both visual and olfactory cues to locate honey bees [39].

Honey bees attract the attention of the hornets thanks to the production of geraniol, component of the aggregation pheromone of the colony. Less effective than pollen and honey, but still attractive is the royal jelly, thanks to the presence of homovanillyl alcohol (HVA) and methyl-4hydrobenzoate (HOB), substances that are part of the pheromone produced by the honey bee queens, but also present in the royal jelly. Betaocimene emitted by larvae also produces olfactory stimuli that are very attractive to hornets [37].

The pheromones produced by the hornet colony's components are being studied for their possible use in biological control techniques [40]. Couto et al. [41], in a neurobiological works on V. v. nigrithorax, showed the presence of several microstructures in the antennal lobe of the males, which are probably linked to sex pheromones. Recently Wen et al. [42] announced the isolation of the sex pheromones from $V$. velutina queens. Cheng et al. [43] proved that $V$. velutina uses sting venom volatiles as an alarm pheromone. 


\section{Impacts}

In Europe, $V . v$. nigrithorax is considered invasive, both for its expansion capabilities at European scale [44-46] and the impacts that it could produce by preying on honey bees and native insects [35,47-49]. The species can cause serious damage and imbalances to biodiversity and ecosystems in areas where it has been introduced. This is aided by $V$. $v$. nigrithorax's high reproductive rate, high dispersal ability, broad diet, wide habitat preference, superior competitive ability, and most importantly, multiple mating of its queens $[13,50,51]$.

Although the species is not considered in Europe more dangerous than native hornets and wasps [52], it can cause problems to human-health and several accidents and some fatal events were recorded [53]. Moreover, by frequently establishing colonial nests in urban areas, V. v. nigrithorax could generate social impacts due to citizens' perception of fear of possible stings [54-56]. V. v. nigrithorax causes multiple threats, however the extent of the impacts produced has not yet been documented and quantified exhaustively. Despite this lack, it is possible to assess the components and/or the activities that are affected or may be impacted by this hornet. From the analysis of the research conducted so far in Europe it is possible to reckon three major negative impacts that the species may create:

1. Economic threats: Loss of honey bee colonies and decreasing of beekeeping products; cost for control activities and nests removal;

2. Ecological threats: Impacts on biodiversity; impacts on pollination activity; competition with native species;

3. Public health threats: Potential risk for citizens.

\subsection{Damage to Beekeeping}

The hornets hunt foraging honey bees returning to their colonies by hovering in front of the hive entrance, grabbing the honey bees in flight, and killing them with their jaws. The thorax is then selected, for the high protein content provided by the flight muscles, and transported to the nest to be fed to the larvae.

The intense predatory activity of $V . v$. nigrithorax towards honey bees can generate a decrease in the strength of the honey bees colonies and the subsequent collapse of the family. This is due to the increase in the number of foraging bees which do not come back in their hive with a consequent increase of the overall probability of homing failure and finally with the disruption of colony foraging activities, which leads to complete foraging paralysis [57]. This primarily generates economic damage to the beekeeping sector, as well as a decrease in the number of honey bees in the environment, resulting in a decline in the ecosystem pollination service.

In some European regions, predation of $V$. v. nigrithorax has resulted in the loss of almost $50 \%$ of bee hives. In the south-west of France, beekeepers reported losses of between $30 \%$ and $80 \%$ of honey bee families, resulting in poor production of honey and other beehive products. In 2010 in Gironde (France), due to V. v. nigrithorax, the Union Nationale pour l'Apiculture Francaise declared that $30 \%$ of bee hives were destroyed or weakened [58]. In Western Liguria (Italy) the authors of the present review (unpublished results) have found an increase of $18 \%$ in winter colony losses in areas where $V . v$. nigrithorax is not controlled.

The costs incurred both for the implementation of public information campaigns and for the destruction of V. v. nigrithorax nests are relevant economic issues. In 2011 in France, the beekeepers' organization Groupement de Dèfense Sanitaire des Abeilles (GDSA) coordinated the destruction of more than 1,000 nests in Aquitania, while a private company destroyed about 500 nests in the Toulouse area. The total cost of these interventions can be quantified to more than 165,000 euros.

Leza et al. [21] demonstrated that the presence of $V$. $v$. nigrithorax produces an increase of oxidative stress in honey bee workers under field conditions. This leads to a higher expression and activity of antioxidant enzymes and mitochondrial-related genes and higher lipid oxidative damage in the individuals of the colony exposed to this predator. Other authors reported that other 
stressors, like herbicides or migratory management, could increase lipid peroxidation in honey bees [59] suggesting that these situations, along with the presence of $V$. $v$. nigrithorax, could affect honey bees' health [21].

The apiaries are a very attractive source of food for $V$. $v$. nigrithorax, because there is a high concentration of honey bees. Studies performed in France have demonstrated that in urbanized environments, where the concentration of apiaries is high, the diet of $V$. $v$. nigrithorax is composed for almost 70\% of honey bees and other similar species (Apoidea) [60]. Monceau et al. [49] monitored the predation of $V . v$. nigrithorax on apiaries. In an apiary with six beehives, in the sampling period they caught a total of 360 workers, and most of these visited the apiary daily. This indicates that once the species has identified an important protein source such as an apiary, it visits the site every day, probably because of a greater success of predation. Of the six beehives monitored in the season, one was completely destroyed, while in the other five the size of the colonies halved. In addition, five $V$. v. nigrithorax nests were discovered within $1 \mathrm{~km}$ from the experimental apiary; so it is likely that apiaries were attacked by individuals from different colonies.

The colonies of Apis mellifera manifest a certain defensive ability towards Vespa crabro, the European native hornet, but fail to implement effective defensive behaviours towards $V$. v. nigrithorax, having had no opportunity to co-evolve with this predator. In the Asian regions, where the local bee species, Apis cerana, has co-evolved with $V$. $v$. nigrithorax, the honey bees have instead developed very effective defense techniques, resulting in suffocation and heating of the predator (balling), and the formation of a compact agglomeration of honey bees on the flying board [61]. A. mellifera is also able to curl up hornets that rest on the flying board of hives, but this behavior does not reach large percentages of success.

At the end of summer, when the colonies of $V$. $v$. nigrithorax are very populous, hornets can get to besiege the hives and penetrate inside them annihilating the colonies of honey bees. The use of doors with passages less than $5.5 \mathrm{~mm}$ in diameter can prevent the entrance of hornets and delay the definitive collapse of the colonies, but if the beekeeper does not intervene to eliminate hornets, the honey bees cannot get out and the colony is destined to collapse (Figure 3).

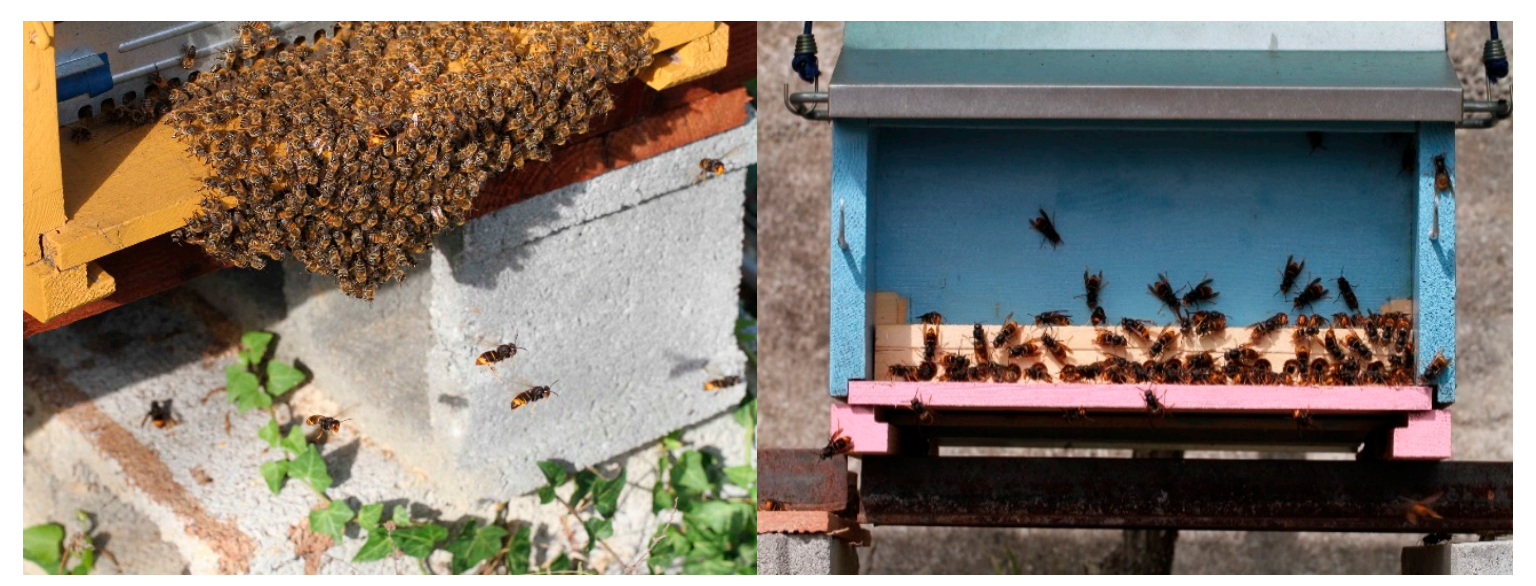

Figure 3. V. v. nigrithorax in hunting activity in front of a hive (left) and heavy attack of hornets on the flying board of a hive (right).

As it often happens in many species of insects, climatic conditions, especially temperature and humidity, affect the predator's activities. In the case of V. v. nigrithorax, the increase in the efficiency of predation, which is most evident in the middle hours of the day, would be the result of an increase in temperatures and the level of solar radiation [38]. 


\subsection{Impact on Ecosystem}

The predatory activity of $V . v$. nigrithorax has a negative impact on insect communities, reducing their abundance and may cause damage to local biodiversity even at the ecosystem level. The predation pressure known in apiaries since the month of July may have similar effects also on other pollinating insects, creating a decline in pollination effectiveness. In fact, besides honey bees, $V$. $v$. nigrithorax preys on other Hymenoptera, including different species of wild bees and other Vespidae (wasps in general), but also Diptera (flies and mosquitoes), butterflies species and other insects. Species preyed upon by $V . v$. nigrithorax and their proportion varies according to the prey availability in the environment. A French study showed that in an urban environment, $V$. $v$. nigrithorax preys mostly honey bees and other Apoidea (66\% of the diet), while in a woodland environment, bees and other Apoidea drop to $33 \%$ and Diptera increase to $32 \%$ [60] (Figure 4).

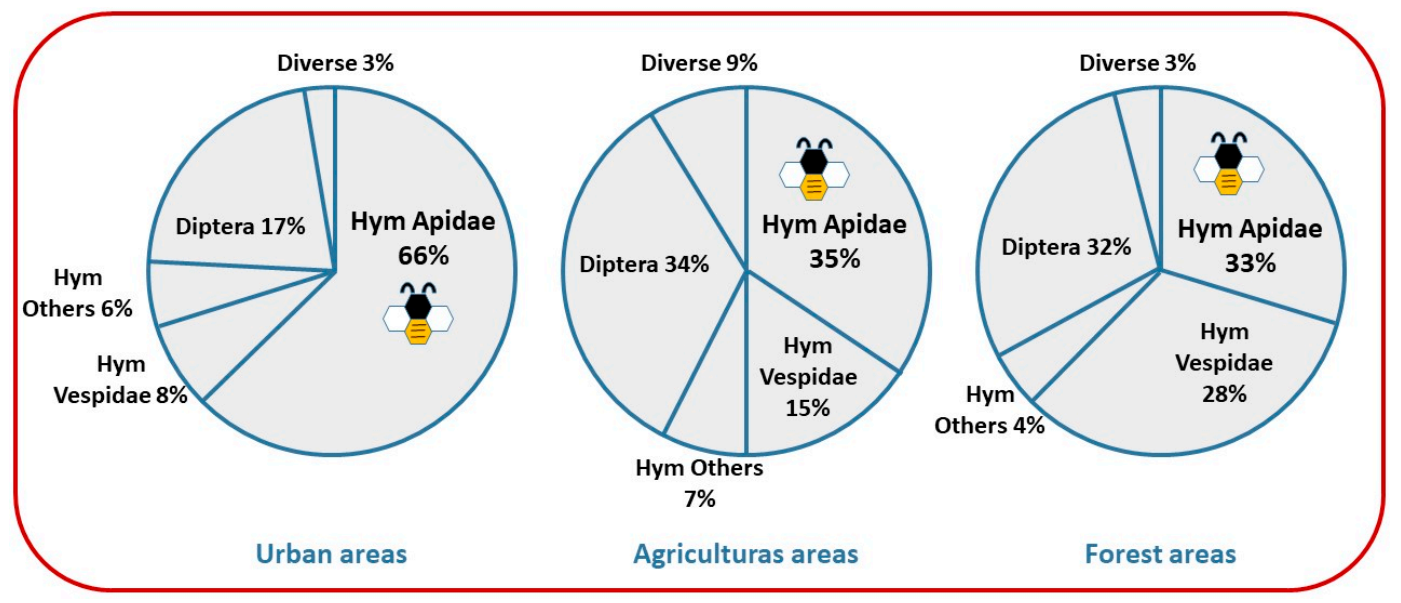

Figure 4. V. v. nigrithorax prey spectrum: Preliminary results in three different environments [60].

\section{Monitoring and Surveillance Systems}

Monitoring the spread of an invasive alien species is crucial to plan appropriate management actions and activities to limit its expansion. Only monitoring and surveillance strategies permit to assess the presence of the species on the territory and identify the areas of expansion or new invasive outbreaks. Since $V$. v. nigrithorax is particularly attracted by honey bees, it is important to involve beekeepers and beekeeper associations to maximize the efficacy of monitoring strategies, together with the contribution of all interested citizens.

An early detection of $V$. v. nigrithorax in areas far away from the expansion front allows to perform a rapid response aimed to remove these isolated populations before the settlement of the species [62]. In fact, $V$. v. nigrithorax queens might be accidentally transported by human activities in very remote areas, where these insects can give rise to new colonies and populations [26]. An early warning and rapid response system (EWRRS) for V. v. nigrithorax is based on three key moments (Figure 5).

Results of EWRRS are the rapid detection of the species and the readiness of intervention, which increases the probability of destroying the colonies before the birth and the mating of the future founder queens. This increases the probability of success in the containment of $V$. $v$. nigrithorax. Key aspects of an effective management strategy are: Simplicity of the procedures; rapid intervention; exportability on a national and international scale; economic sustainability.

Different monitoring methods for $V . v$. nigrithorax exist: Direct observations of hornets in apiaries or on flowers and the use of traps.

Several trap models have been proposed to catch $V$. v. nigrithorax adults; basically, they can be reduced to bottle, funnel, and sticky traps or to a combination of them.

In addition to proprietary baits, many types of self-produced carbohydrate or protein baits can be used. Sugar based baits include beer, vinegar, grenadine, acetic acid, fermented honeycomb juice, 
honey, different type of sweeteners mixtures, etc. [40]. They are better used between February and May, so to catch the founder queens when they begin the construction of the primary nests, and from August until November, to detect the presence of the species in new areas or to catch the reproductive adults. Demichelis et al. [24] recommend the use of lager beer ( 0.33 litres with $4.7 \%$ alcohol), because it is attractive for the hornets, inexpensive, and selective towards honey bees (Figure 6).

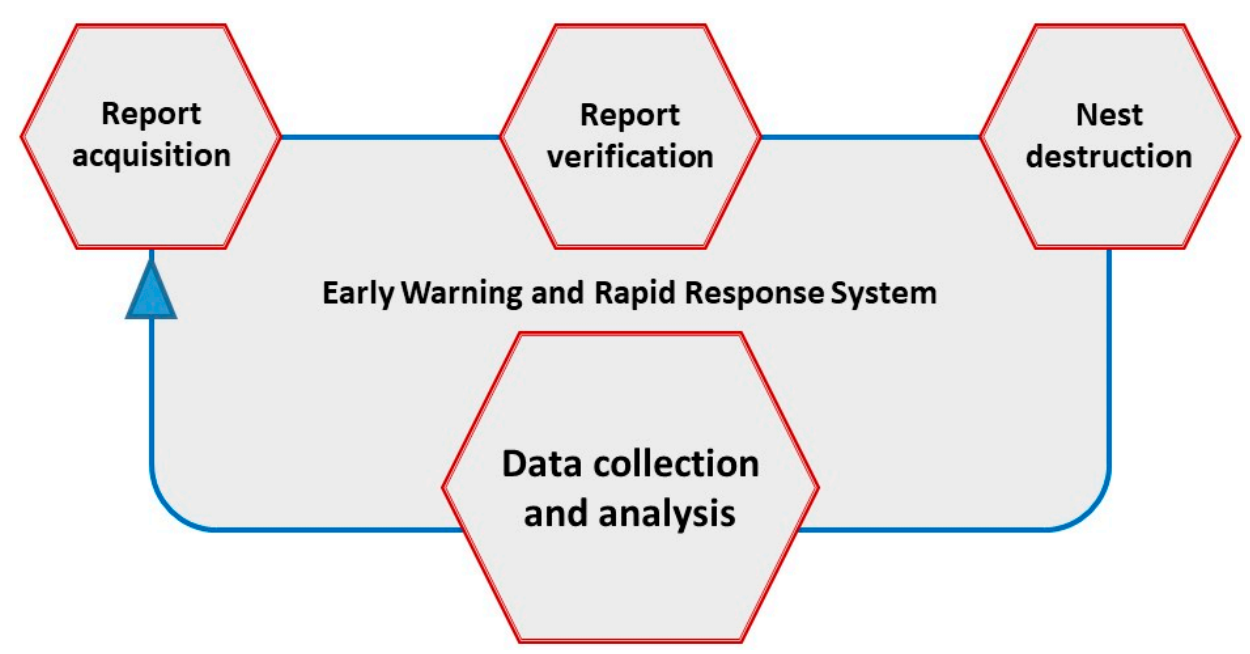

Figure 5. Early warning and rapid response system for $V$. v. nigrithorax.

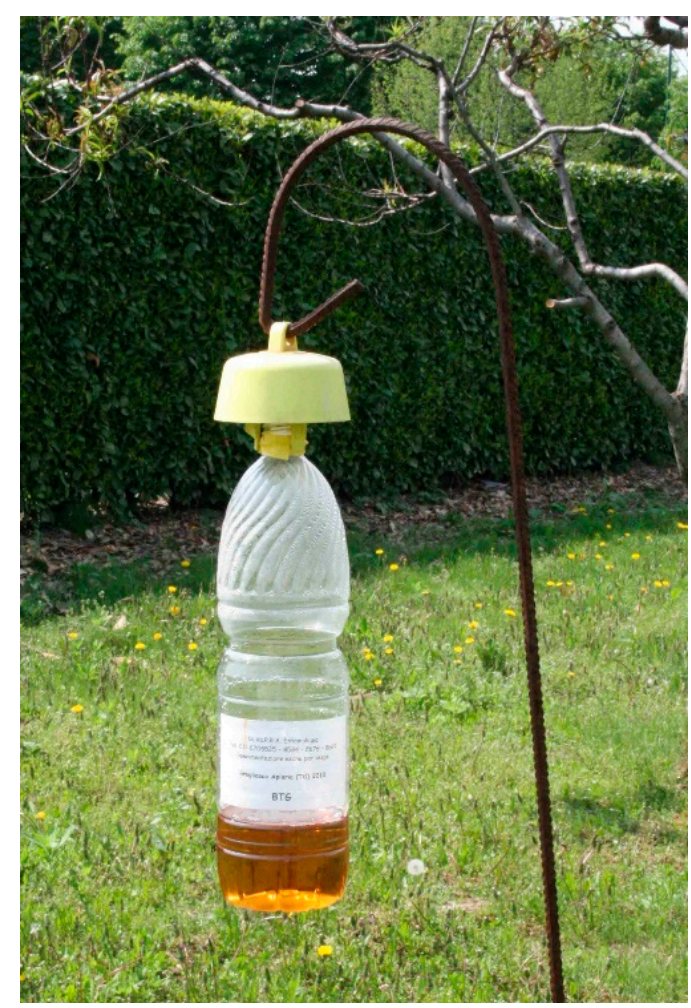

Figure 6. Bottle trap with lager beer [24].

During colony development, between June and August, protein baits (meat, fish, etc.) can be used. In addition, Rodríguez-Flores et al. [18] highlighted that elevation and meteorological factors influence the effectiveness of bait trapping. 


\section{Control}

Control invasive alien species is difficult and expensive in the long term; therefore, every effort should be undertaken to prevent their establishment and diffusion in new areas. The many methods developed to control $V . v$. nigrithorax in Europe and in Asia outside of its native range have been previously reviewed $[9,33,35,40,47]$.

Until now, no single control method has proved to be fully effective, but the coordinated use of several methods under an integrated pest management approach should greatly reduce the impact of V. v. nigrithorax on honey bees and on the environment (Figure 7).

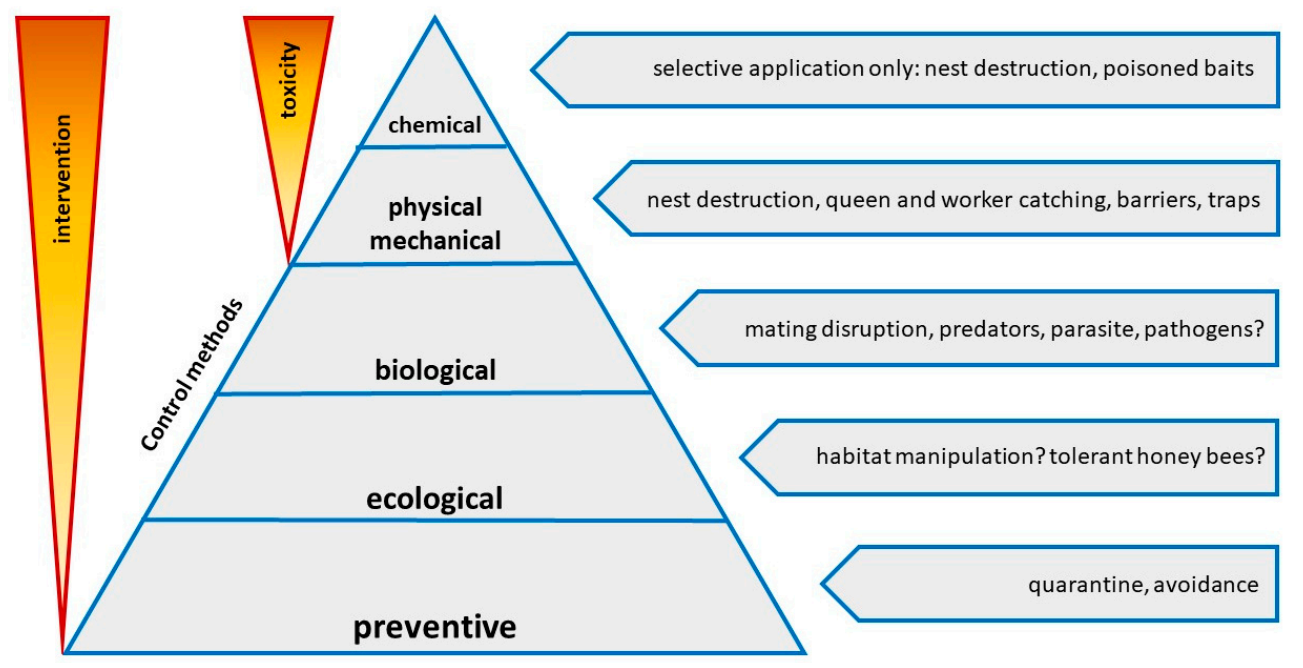

Figure 7. Integrated pest management pyramid showing available or possible methods to control V. $v$. nigrithorax, from the low intervention and not toxic preventive methods to the high impact chemical methods that implies the use of toxic insecticides.

Control efforts may implemented against adult hornets or nests. In the first case, the baited traps used for monitoring purposes can be used either for controlling purposes, but traps are at the moment not selective enough to prevent extensive captures of non-target insects, with possible extensive impacts to native species [57,63]. Other types of control techniques are used or tested in Europe: Bucket poisoned baits, passive traps, electric traps, electric harps, badminton rackets, beehive muzzles, nest gunshot, or the use of the hornet workers as poison carriers [40].

The detection and destruction of the nests of V. v. nigrithorax is currently the most effective control method, especially when the nests themselves are destroyed before the reproductive phase of the colony which normally occurs in early September. In any case, it is important to search for and destroy active nests in all stages from foundation to winter [53]. Once a nest has been located, it must be destroyed in a complete way, paying special attention to killing the queen, the majority of the workers, and all the brood present in the combs.

The discovered nests should be immediately destroyed by people with specific training and equipped with suitable personal protective clothes and the necessary tools. The methods of intervention are various in relation to the place where the nests are built and the size of the colonies.

Nests are generally treated with insecticides for hornets and wasps, using also special extendable rods capable of reaching nests that are in high positions (Figure 8).

The control of the populations of $V$. v. nigrithorax is hindered by the difficulty of finding all nests. Embryo nests are small and difficult to observe; later the nests, although very voluminous, are often difficult to be located since covered by tree canopy. In fact, $V$. $v$. nigrithorax can build nests in several environments, such as natural, rural, and urban areas, and on different substrates [18]. They can be found on trees, shrubs, roofs or balconies of houses, inside gaps, but also in soil cavities or on rocky substrates (Figure 9). 

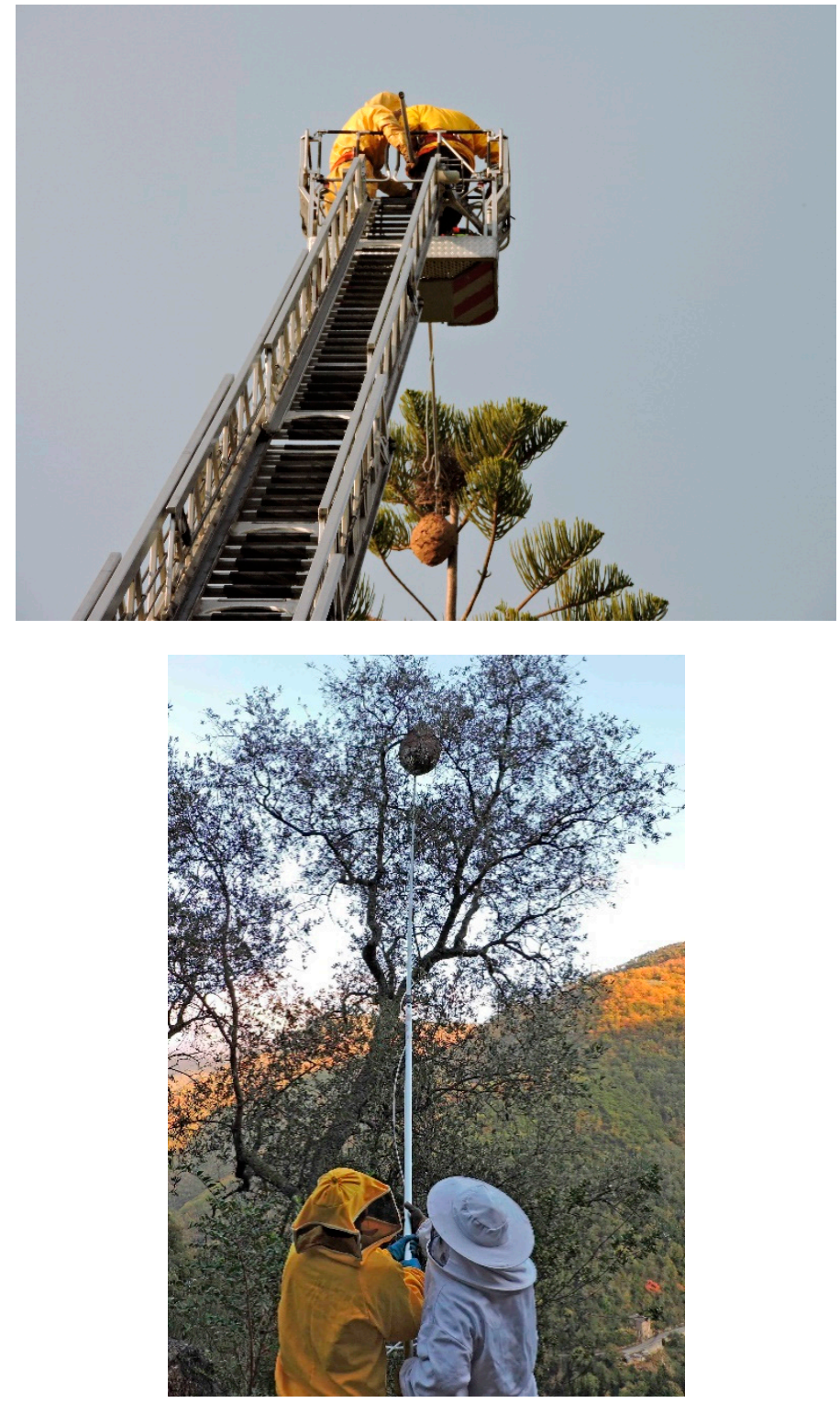

Figure 8. Different methods to destroy the nests depending on their position.

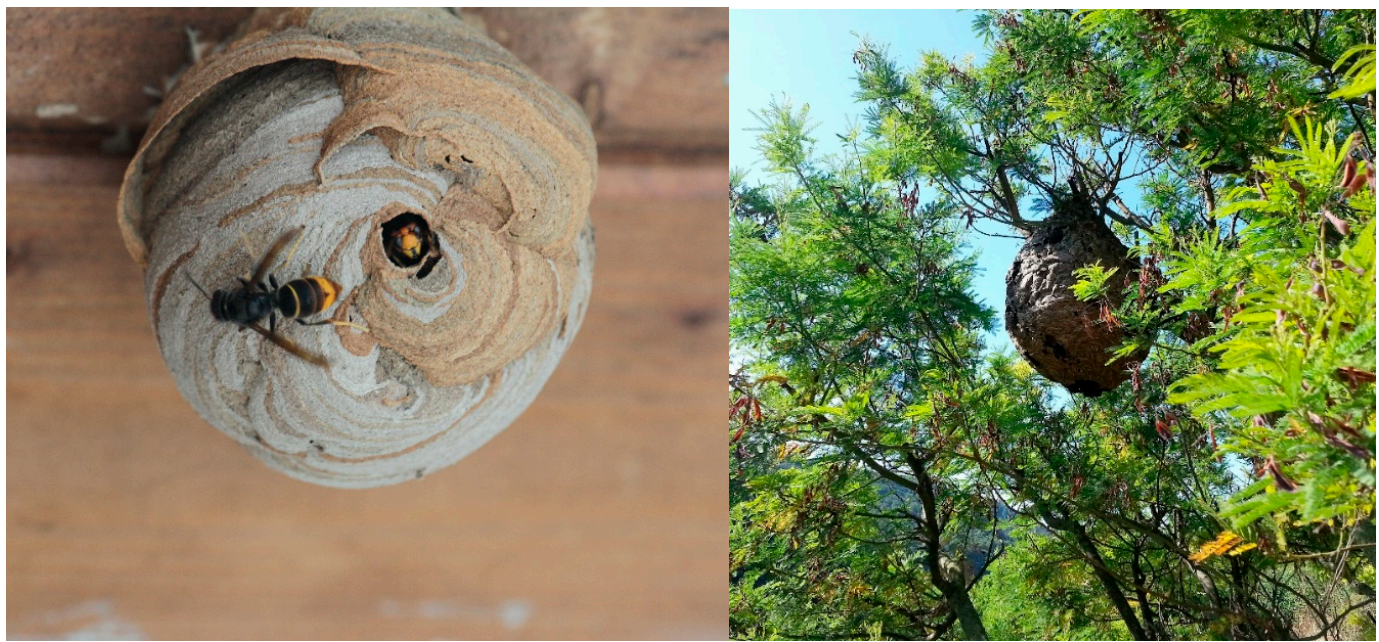

Figure 9. Primary nest built under a roof canopy (left) and secondary nest (right) built on Acacia dealbata tree in Liguria Region (Italy). 


\subsection{Nest Detection}

Several techniques are currently available to locate hornet nests, but they are all tedious, extremely labor consuming, and/or expensive [40].

The triangulation involves capturing at least three specimens and their subsequent release from various locations, in order to recording the direction of their flight; if the hornets tend to return in a straight direction, there is a good chance that the three directions they took would intersect at a point that will correspond to nest position [20,64]. The on-view tracking of tagged hornets, which are made more evident with a feather or a cotton, has been suggested [65]. The drone-assisted nest tracking, a theoretical study that uses several drones equipped with cameras capable of analysis an image of a hornet marked with a thread carrying a fluorescent Styrofoam ball, has recently been published [66].

Alternatively to these observational methods, it is possible locate the nests by using equipment developed in recent years.

The infrared thermal imaging camera has been tested in Portugal, in UK [67,68], and in Italy [69].

Radio-telemetry has been implemented in UK as a tool for tracking hornets back to their nests and providing an efficient mean of finding nests in complex environments [68].

A European LIFE project (LIFE STOPVESPA) has just been completed to contain the spread of V. v. nigrithorax in Italy by implementing an EWRRS (https://www.vespavelutina.eu/en-us/). For this reason, two prototypes of harmonic entomological radars able to track the flight of hornets in real time and quickly locate the position of nests were developed by the Polytechnic University of Turin (Italy). The radars are capable to follow the flight of hornets equipped with a passive transponder (tag). The radar emits a series of short pulses at a given frequency $(9.41 \mathrm{GHz})$, which are then retransmitted at a double frequency (for this reason, it is called 'harmonic') by the tag fixed on the thorax of the hornets (Figure 10) [70,71]. The tracks obtained allow to follow the path of the hornets and locate the nests. Thanks to the high transmission power, a wide maximum operating distance of $490 \mathrm{~m}$ was obtained [72].
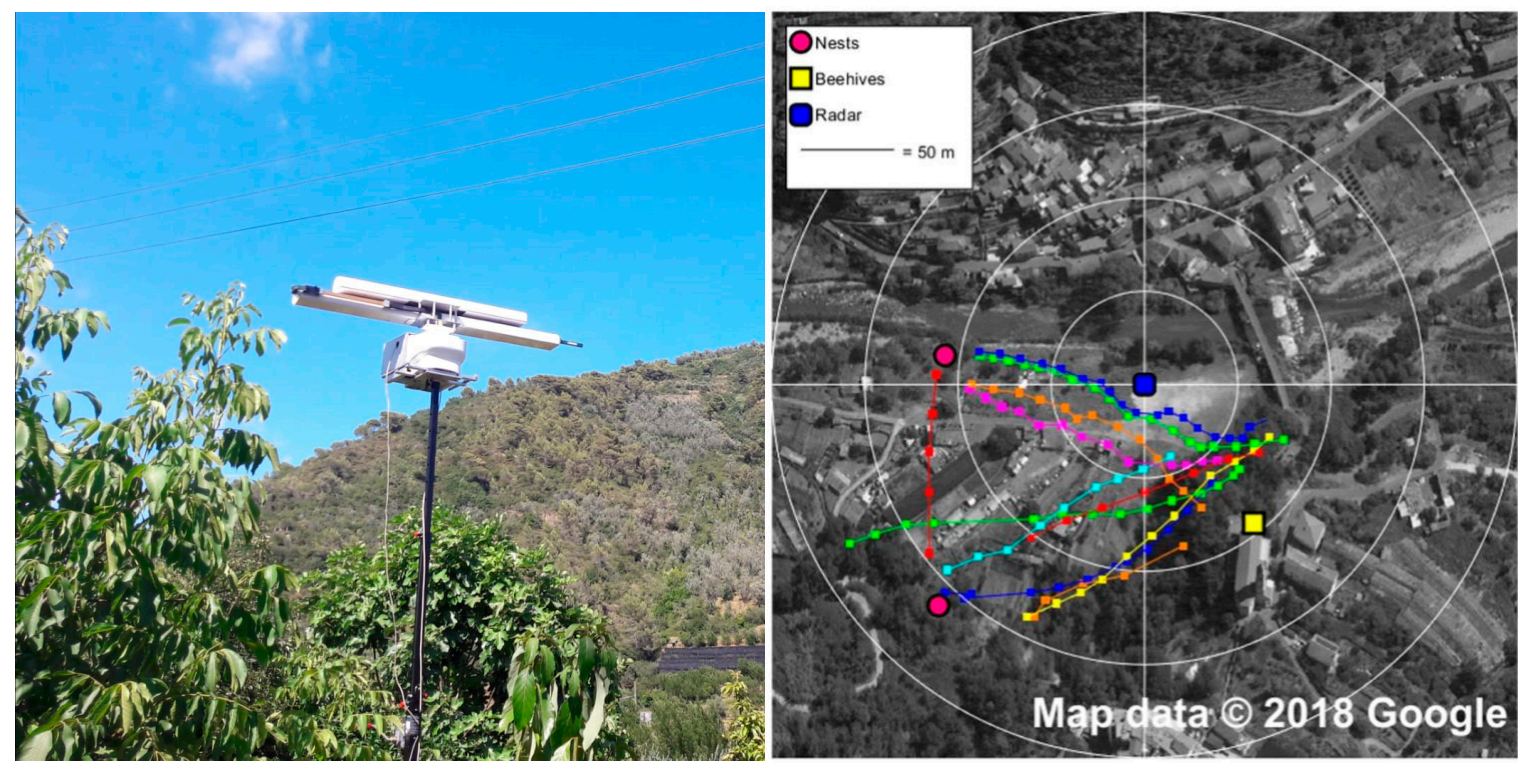

Figure 10. Harmonic radar able to follow the flight of hornets equipped with a passive transponder (left). On the map, the tracks obtained allowed to follow the path of the hornets and locate the nests (right).

\subsection{Biological Control}

Identifying organisms capable of parasitizing hornets could allow the selection of potential control agents, always remembering that they could also be transmitted to native species. At the moment, there are no known effective enemies or adversities in Europe that could be used for the biological 
control of V. v. nigrithorax. The main limitation for a biological control program is the lack of knowledge of the biology and ecology of $V$. v. nigrithorax in both the native and invaded territory.

In Asia V. v. nigrithorax is parasitized by Bareogonalos jezoensis (Yamane, 1973) (Hymenoptera Trigonalidae), but its use in biological control cannot be considered as a fighting agent in Europe since it would also parasitize other species of wasps or other insects. Before any use of parasites or other exotic biological agents, preventive and rigorous verifications are always necessary to rule out any effects on other native species [73].

In France, larval forms of the Conops vesicularis (Diptera Conopidae) were found, inside the abdomen of some individuals of $V$. v. nigrithorax, which resulted in their death [57,74]. Spradbery [75] reports that adults of $C$. vesicularis can wait at the entrance of the nest for homing workers, attack them and oviposit their eggs. So individuals of $V$. $v$. nigrithorax may be parasitized by this species in the environment, during foraging activity, or near the nest. However, the effectiveness of $C$. vesicularis as a biological agent for controlling $V . v$. nigrithorax populations appears limited.

Another potential parasite of $V$. v. nigrithorax has been confirmed by Villemant et al. [76], with the discovery of Pheromermis vesparum (Nematoda Mermithidae). This parasite was found in adult specimens of V. v. nigrithorax in France on two occasions, in November 2012 at Dompierre-sur-Besbre, and in January 2013 in Issigeac. However, even in this case, its effectiveness as biological control agent appears limited, as they are the only two cases of nematodes found on $V$. v. nigrithorax specimens throughout Europe.

In France, an entomopathogenic fungus (Beauveria bassiana) has been described to infect the common wasp Vespula vulgaris [77]. French researchers are studying if it is therefore likely to infect other hornets such V. v. nigrithorax. Poidatz et al. [78] describe Metarhizium robertsii as potential biological control agents against the invasive hornet $V$. $v$. nigrithorax.

Some species of mammals (as Meles meles) and birds (as Garrulus glandarius, Merops apiaster, Parus major, Pica pica, Sitta europaea, and Gallus gallus domesticus) can prey upon V. v. nigrithorax, but the predatory activity carried out by these animals is essentially sporadic and not enough to limit the population of the hornet; Pernis apivorus was also reported to exploit active V. v. nigrithorax nests [38,79].

\section{Conclusions}

The alien species $V . v$. nigrithorax, since its accidental introduction in France, has now successfully colonized several European countries. In the areas in which it has settled, it has become clear that it has a negative effect on $A$. mellifera, documented by the numerous losses of beehives reported by beekeepers. Hornets concentrate their predation activity on the honey bee colonies as they provide an abundant and continuous source of food. V. v. nigrithorax, however, hunts numerous other insects present in the environment and, among them, wild bees, attacking them while they are on the flowers intent on collecting nectar and pollen. This activity removes from the environment insects that play a very important ecosystem role. In fact, by visiting cultivated and spontaneous plants, wild pollinators guarantee not only the production of seeds and fruits of economic interest, but also the biodiversity of spontaneous plants.

Recent studies have shown that in Europe, and on other continents, pollinating insects and honey bees are in decline due to a combination of multiple factors. There is no doubt that the accidental introduction of the invasive predator $V$. v. nigrithorax can aggravate the situation. In fact, the Asian yellow-legged hornet has widely contributed to the decrease in the colonies of honey bees, weakening them to such an extent that they collapse and are more susceptible to parasites, viruses, and fungi.

Given the fundamental role of natural pollinators, studies are currently under way to ascertain the real effects of $V . v$. nigrithorax on wild bee populations and, more generally, on the environment in the newly introduced areas.

The introduction of an invasive exotic species, as well as causing damage to the ecosystem and biodiversity, can also generate a great deal of damage to the economy. $V$. v. nigrithorax has a negative impact, particularly on agriculture. The disappearance of beehives leads to the loss of honey bee 
products, putting the beekeeping industry in the position to be out of the market due to lack of production and/or rising of production costs. This type of economic impact is currently the most studied and can be easily expressed in monetary values.

The reduction in production yields of crops, as a result of the reduction of pollinators in general, is not quantifiable at the moment.

Author Contributions: Conceptualization, D.L. and A.M.; validation, S.L. and L.C.; literature investigation, D.L., A.M. and M.P.; data curation, D.L., S.L. and L.C.; writing-Original draft preparation, D.L.; writing-Review and editing, D.L. and S.L.; visualization, D.L. and L.C.; supervision, M.P.; project administration, S.L.; funding acquisition, M.P. All authors have read and agreed to the published version of the manuscript.

Funding: The paper was published thanks to University of Turin funds but should be considered as an After-LIFE product of the LIFE14 NAT/IT/001128 STOPVESPA funded by the European Commission.

Conflicts of Interest: The authors declare no conflict of interest, the absence of any personal circumstances or interest that may be perceived as inappropriately influencing the representation or interpretation of reported research results. The funder had no role in the design of the study; in the collection, analyses, or interpretation of data; in the writing of the manuscript, or in the decision to publish the results.

\section{References}

1. Atkinson, I.A.E. Introductions of wildlife as a cause of species extinctions. Wildl. Biol. 1996, 2, $135-141$. [CrossRef]

2. Gandhi, K.J.K.; Herms, D.A. Direct and indirect effects of alien insect herbivores on ecological processes and interactions in forests of eastern North America. Biol. Invasions 2010, 12, 389-405. [CrossRef]

3. Lever, C. Silent Summer: The State of Wildlife in Britain and Ireland_Vertebrate Animal Introductions; Maclean, N., Ed.; Cambridge University Press: Cambridge, UK, 2010; Volume 4, pp. 36-52.

4. Van der Vecht, J. The Vespinae of the Indo Malayan and Papuan areas (Hymenoptera, Vespidae). Zool. Verh. $1957,34,1-83$.

5. Van der Vecht, J. Notes on Oriental Vespinae, including some species from China and Japan (Hymenoptera, Vespidae). Zool. Meded. 1959, 36, 205-232.

6. Archer, M.E. Taxonomy, distribution and nesting biology of the Vespa bicolor group (Hym., Vespinae). Entomol. Mon. Mag. 1994, 130, 149-158.

7. Perrard, A.; Arca, M.; Rome, Q.; Muller, F.; Tan, J.; Bista, S.; Ho, H.N.; Baudoin, R.; Baylac, M.; Silvain, J.F.; et al. Geographic variation of melanisation patterns in a hornet species: Genetic differences, climatic pressures or aposematic constraints? PLoS ONE 2014, 9, e94162. [CrossRef]

8. Archer, M.E. Vespine Wasps of the World. Behaviour, Ecology and Taxonomy of the Vespinae; Monograph Series; Siri Scientific Press: Manchester, UK, 2012; Volume 4, pp. 1-352. ISBN 978-0-9567795-7-1.

9. Choi, M.B.; Martin, S.J.; Lee, J.W. Distribution, spread, and impact of the invasive hornet Vespa velutina in South Korea. J. Asia Pac. Entomol. 2012, 15, 473-477. [CrossRef]

10. Sakay, Y.; Takahashi, J. Discovery of a worker of Vespa velutina (Hymenoptera: Vespidae) from Tsushima Island, Japan. Jpn. J. Entomol. 2014, 17, 32-36.

11. Ueno, T. Establishment of the invasive hornet Vespa velutina (Hymenoptera: Vespidae) in Japan. Int. J. Chem. Environ. Biol. Sci. 2014, 2, 220-222.

12. Minoshima, Y.N.; Yamane, S.; Ueno, T. An invasive alien hornet, Vespa velutina nigrithorax du Buysson (Hymenoptera, Vespidae), found in Kitakyushu, Kyushu Island: A first record of the species from mainland Japan. Jpn. J. Syst. Entmol. 2015, 21, 259-261.

13. Takahashi, J.; Okuyama, H.; Kiyoshi, T.; Takeuchi, T.; Martin, S.J. Origins of Vespa velutina hornets that recently invaded Iki Island, Japan and Jersey Island, UK. Mitochondrial DNA 2018, 1-6. [CrossRef] [PubMed]

14. Haxaire, J.; Bouguet, J.P.; Tamisier, J.P. Vespa velutina Lepeletier, 1836, une redoutable nouveauté pour la faune de France (Hym., Vespidae). Bull. Soc. Entomol. Fr. 2006, 111, 194.

15. Villemant, C.; Haxaire, J.; Streito, J.L. Premier bilan de l'invasion de Vespa velutina Lepeletier en France (Hymenoptera, Vespidae). Bull. Soc. Entomol. Fr. 2006, 111, 535-538.

16. Castro, L.; Pagola-Carte, S. Vespa velutina Lepeletier, 1836 (Hymenoptera: Vespidae) recolectada en la Penınsula Iberica. Heteropterus Rev. Entomol. 2010, 10, 193-196. 
17. Lopéz, S.; Gonzalez, M.; Goldarazena, A. Vespa velutina Lepeletier, 1836 Hymenoptera: Vespidae): First records in Iberian Peninsula. Bull. OEPP/EPPO Bull. 2011, 41, 439-441. [CrossRef]

18. Rodríguez-Flores, M.S.; Seijo-Rodríguez, A.; Escuredo, O.; Seijo-Coello, M.C. Spreading of Vespa velutina in northwestern Spain: Influence of elevation and meteorological factors and effect of bait trapping on target and non-target living organisms. J. Pest Sci. 2019, 92, 557-565. [CrossRef]

19. Pujade-Villar, J.; Torrel, A.; Rojo, M. Confrimada la presència a CAtalunyad'una vespa originària d'Asia molt perillosa per als ruscs. Butll. Inst. Cat. Hist. Nat. 2012, 77, 173-176.

20. Leza, M.; Miranda, M.A.; Colomar, V. First detection of Vespa velutina nigrithorax (Hymenoptera: Vespidae) in Balearic Islands (Western Mediterranean): A challenging study case. Biol. Invasions 2018, 1-7. [CrossRef]

21. Leza, M.; Herrera, C.; Marques, A.; Roca, P.; Sastre Serra, J.; Pons, D.G. The impact of the invasive species Vespa velutina on honeybees: A new approach based on oxidative stress. Sci. Total Environ. 2019, 689, 709-715. [CrossRef]

22. Grosso-Silva, J.M.; Maia, M. Vespa velutina Lepeletier, 1836 (Hymenoptera, Vespidae), new species for Portugal. AEGA 2012, 6, 53-54.

23. Rome, Q.; Muller, F.; Villemant, C. Expansion en 2011 de Vespa velutina Lepeletier en Europe (Hym., Vespidae). Bull. Soc. Entomol. Fr. 2012, 117, 114.

24. Demichelis, S.; Manino, A.; Minuto, G.; Mariotti, M.; Porporato, M. Social wasp trapping in north west Italy: Comparison of different bait-traps and first record of Vespa velutina Lepeletier (Hymenoptera: Vespidae). Bull. Insectol. 2014, 67, 307-317. [CrossRef]

25. Porporato, M.; Manino, A.; Laurino, D.; Demichelis, S. Vespa velutina Lepeletier (Hymenoptera Vespidae): A first assessment two years after its arrival in Italy. Redia 2014, 97, 189-194.

26. Bertolino, S.; Lioy, S.; Laurino, D.; Manino, A.; Porporato, M. Spread of the invasive yellow legged hornet Vespa velutina (Hymenoptera: Vespidae) in Italy. Appl. Entomol. Zool. 2016, 51, 589-597. [CrossRef]

27. Lioy, S.; Manino, A.; Porporato, M.; Laurino, D.; Romano, A.; Capello, M.; Bertolino, S. Establishing surveillance areas for tackling the invasion of Vespa velutina in outbreaks and over the border of its expanding range. Neobiota 2019, 46, 51-69. [CrossRef]

28. Witt, R. Erstfund eines Nestes der Asiatischen Hornisse Vespa velutina Lepeletier, 1838 in Deutschland und Details zum Nestbau (Himonoptera, Vespinae). Ampulex 2015, 7, 42-53.

29. UK National Bee Unit. 2016. Available online: http://nationalbeeunit.com/ (accessed on 9 April 2019).

30. Budge, G.E.; Hodgetts, J.; Jones, E.P.; Ostojà-Starzewski, J.C.; Tomkies, V.; Semmence, N.; Brown, M.; Stainton, K. The invasion provenance and diversity of Vespa velutina Lepeletier (Hymenoptera: Vespidae) in Great Britain. PLoS ONE 2017, 12, 1-12. [CrossRef]

31. Villemant, C.; Barbet-Massin, M.; Perrard, A.; Muller, F.; Gargominy, O.; Jiguet, F.; Rome, Q. Predicting the invasion risk by the alien bee-hawking Yellow-legged hornet Vespa velutina nigrithorax across Europe and other continents with niche models. Biol. Conserv. J. 2011, 144, 2142-2150. [CrossRef]

32. Barbet-Massin, M.; Rome, Q.; Muller, F.; Perrard, A.; Villemant, C. Climate change increases the risk of invasion by the Yellow-legged hornet. Biol. Conserv. 2013, 157, 4-10. [CrossRef]

33. Kishi, S.; Goka, K. Review of the invasive yellow-legged hornet, Vespa velutina nigrithorax (Hymenoptera: Vespidae), in Japan and its possible chemical control. Appl. Entomol. Zool. 2017, 52, 361-368. [CrossRef]

34. Rome, Q.; Muller, F.J.; Touret-Alby, A.; Darrouzet, E.; Perrard, A.; Villemant, C. Caste differentiation and seasonal changes in Vespa velutina (Hym.: Vespidae) colonies in its introduced range. J. Appl. Entomol. 2015, 139, 771-782. [CrossRef]

35. Monceau, K.; Bonnard, O.; Thiery, D. Vespa velutina: A new invasive predator of honeybees in Europe. J. Pest Sci. 2014, 87, 1-16. [CrossRef]

36. Wang, Z.; Qu, Y.; Dong, S.; Wen, P.; Li, J.; Tan, K.; Menzel, R. Honey bees modulate their olfactory learning in the presence of hornet predators and alarm component. PLoS ONE 2016, 11, 1-12. [CrossRef]

37. Couto, A.; Monceau, K.; Bonnard, O.; Thiéry, D.; Sandoz, J.C. Olfactory attraction of the hornet Vespa velutina to honeybee colony odors and pheromones. PLoS ONE 2014, 9, 1-19. [CrossRef]

38. Laurino, D.; Porporato, M. Vespa Velutina-Conoscerla e Prepararsi ad Affrontare il Pericolo, 1st ed.; Edizioni Montaonda: San Godenzo, Italy, 2017; p. 67. ISBN 9-78898-186228.

39. Wang, Z.W.; Chen, G.; Tan, K. Both olfactory and visual cues promote the hornet Vespa velutina to locate its honeybee prey Apis Cerana. Insectes Soc. 2014, 61, 67-70. [CrossRef] 
40. Turchi, L.; Derijard, B. Options of the biological and physical control of Vespa velutina nigrithorax (Hym.: Vespidae) in Europe: A review. J. Appl. Entomol. 2018, 1, 10. [CrossRef]

41. Couto, A.; Lapeyre, B.; Thiery, D.; Sandoz, J.C. Olfactory pathway of the hornet Vespa velutina: New insights into the evolution of the hymenopteran antennal lobe. J. Comp. Neurol. 2016, 524, 2335-2359. [CrossRef]

42. Wen, P.; Cheng, Y.N.; Dong, S.H.; Wang, Z.W.; Tan, K.; Nieh, J.C. The sex pheromone of a globally invasive honey bee predator, the Asian eusocial hornet, Vespa velutina. Sci. Rep. 2017, 7, 12956. [CrossRef]

43. Cheng, Y.; Wen, P.; Dong, S.; Tan, K.; Nieh, J.C. Poison and alarm: The Asian hornet Vespa velutina uses sting venom volatiles as alarm pheromone. J. Exp. Biol. 2017, 220, 645-651. [CrossRef]

44. Fournier, A.; Barbet-Massin, M.; Rome, Q.; Courchamp, F. Predicting species distribution combining multi-scale drivers. Glob. Ecol. Conserv. 2017, 12, 215-226. [CrossRef]

45. Robinet, C.; Suppo, C.; Darrouzet, E. Rapid spread of the invasive yellow-legged hornet in France: The role of human-mediated dispersal and the effects of control measures. J. Appl. Ecol. 2017, 54, 205-215. [CrossRef]

46. Barbet-Massin, M.; Rome, Q.; Villemant, C.; Courchamp, F. Can species distribution models really predict the expansion of invasive species? PLoS ONE 2018, 13, e0193085. [CrossRef] [PubMed]

47. Beggs, J.R.; Brockerhoff, E.G.; Corley, J.C.; Kenis, M.; Masciocchi, M.; Muller, F.; Rome, Q.; Villemant, C. Ecological effects and management of invasive alien Vespidae. BioControl 2011, 56, 505-526. [CrossRef]

48. Monceau, K.; Maher, N.; Bonnard, O.; Thiery, D. Predation pressure dynamics study of the recently introduced honeybee killer Vespa velutina: Learning from the enemy. Apidologie 2013, 44, 209-221. [CrossRef]

49. Monceau, K.; Bonnard, O.; Moreau, J.; Thiéry, D. Spatial distribution of Vespa velutina individuals hunting at domestic honeybee hives: Heterogeneity at a local scale. Insect Sci. 2014, 21, 765-774. [CrossRef] [PubMed]

50. Moller, H. Lessons for invasion theory from social insects. Biol. Conserv. 1996, 78, 125-142. [CrossRef]

51. Martin, S.J. The Asian hornet: Threats, Biology E Expansion; The International Bee Research Association: England and Wales, 2017; p. 106. ISBN 9780860982814.

52. De Haro, L.; Labadie, M.; Chanseau, P.; Cabot, C.; Blanc-Brisset, I.; Penouil, F. Medical consequences of the Asian black hornet (Vespa velutina) invasion in Southwestern France. Toxicon 2010, 55, 650-652. [CrossRef]

53. Feàs Sanchez, X.; Charles, R.J. Notes on the Nest Architecture and Colony Composition in Winter of the Yellow-Legged Asian Hornet, Vespa velutina Lepeletier 1836 (Hym.: Vespidae), in Its Introduced Habitat in Galicia (NW Spain). Insects 2019, 10, 237. [CrossRef]

54. Liu, Z.R.; Chen, S.G.; Zhou, Y.; Xie, C.H.; Zhu, B.F.; Zhu, H.M.; Liu, S.P.; Wang, W.; Chen, H.Z.; Ji, Y.H. Deciphering the Venomic Transcriptome of Killer-Wasp Vespa velutina. Sci. Rep. 2015, 5, 9454. [CrossRef]

55. Tabar, A.I.; Chugo, S.; Joral, A.; Lizaso, M.T.; Lizarza, S.; Alvarez-Puebla, M.J.; Arroabarren, E.; Vela, C.; Lombardero, M. Vespa velutina nigrithorax: A new causative agent for anaphylaxis. Clin. Transl. Allergy 2015, 5, 43. [CrossRef]

56. Sumner, S.; Law, G.; Cini, A. Why we love bees and hate wasps. Ecol. Entomol. 2018, 43, 836-845. [CrossRef]

57. Requier, F.; Rome, Q.; Chiron, G.; Decante, D.; Marion, S.; Menard, M.; Muller, F.; Villemant, C.; Henry, M. Predation of the invasive Asian hornet affects foraging activity and survival probability of honey bees in Western Europe. J. Pest Sci. 2019, 92, 567-578. [CrossRef]

58. Monceau, K.; Thiery, D. Vespa velutina: Current situation and perspectives. Atti Accad. Naz. Ital. Entomol. 2016, 64, 137-142.

59. Helmer, S.H.; Kerbaol, A.; Aras, P.; Jumarie, C.; Boily, M. Effects of realistic doses of atrazine, metolachlor, and glyphosate on lipid peroxidation and diet-derived antioxidants in caged honey bees (Apis mellifera). Environ. Sci. Pollut. Res. 2015, 22, 8010-8021. [CrossRef]

60. Rome, Q.; Perrard, A.; Muller, F.; Villemant, C. Monitoring and control modalities of a honeybee predator, the Yellow-legged hornet Vespa velutina nigrithorax (Hymenoptera: Vespidae). Aliens Invasive Spec. Bull. 2011, 31, 7-15.

61. Ken, T.; Hepburn, H.R.; Radloff, S.E.; Yusheng, Y.; Yiqiu, L.; Danyin, Z.; Neumann, P. Heat-balling wasps by honeybees. Naturwissenschaften 2005, 92, 492-495. [CrossRef]

62. Genovesi, P.; Scalera, R.; Brunel, S.; Solarz, W.; Roy, D. Towards an Early Warning and Information System for Invasive Alien Species (IAS) Threatening Biodiversity in Europe; Tech. Report 5/2010; European Environment Agency: Copenhagen, Denmark, 2010; 52p. [CrossRef]

63. Rojas-Nossa, S.V.; Novoa, N.; Serrano, A.; Calviño-Cancela, M. Performance of baited traps used as control tools for the invasive hornet Vespa velutina and their impact on non-target insects. Apidologie 2018, 49, 872-885. [CrossRef] 
64. Blot, J. Localisation et destrution des nids de frelons asiatiques. Bull. Tech. Apic. 2008, 35, 95-100.

65. Jeffs, K. Wild China BBC, Hornet Sequence between 42' and 45'. 2008. Available online: http://www.bbc.co.uk/ iplayer/episode/b==brvjx/wild-china-2-shangrila;https://vimeo.com/7877242 (accessed on 15 October 2019).

66. Reynaud, B.; Guérin-Lassous, I. Design of a force-based controlled mobility on aerial vehicles for pest management. Ad Hoc Netw. 2016, 53, 41-52. [CrossRef]

67. Semmence, N. Asian Hornet Update from the National Bee Unit. Incorporating the British Bee J. BBKA News, November 2018; 270-272.

68. Kennedy, P.; Ford, S.M.; Poidatz, J.; Thiéry, D.; Osborne, J.L. Searching for nests of the invasive Asian hornet (Vespa velutina) using radio-telemetry. Commun. Biol. 2018, 1, 88. [CrossRef]

69. Bortolotti, L.; Cervo, R.; Felicioli, A.; Quaranta, M.; Salvetti, O.; Berton, A. Progetto Velutina: La ricerca italiana a caccia di soluzioni. Atti Accad. Naz. Ital. Entomol. 2016, 64, 143-149.

70. Milanesio, D.; Saccani, M.; Maggiora, R.; Laurino, D.; Porporato, M. Design of an harmonic radar for the tracking of the Asian yellow-legged hornet. Ecol. Evol. 2016, 6, 2170-2217. [CrossRef] [PubMed]

71. Milanesio, D.; Saccani, M.; Maggiora, R.; Laurino, D.; Porporato, M. Recent upgrades of the harmonic radar for the tracking of the Asian yellow-legged hornet. Ecol. Evol. 2017, 7, 4599-4606. [CrossRef] [PubMed]

72. Maggiora, R.; Saccani, M.; Milanesio, D.; Porporato, M. An Innovative Harmonic Radar to Track Flying Insects: The Case of Vespa velutina. Sci. Rep. 2019, 9, 1-10. [CrossRef]

73. Yamane, S. New taxa of the genius Bareogonalos from Asia with further information on the tribe Nomadinini (Hymenoptera, Trigonalidae). Halteres 2014, 5, 17-31.

74. Darrouzet, E.; Gérvar, J.; Dupont, S. A scientific note about a parasitoid that can parasitize the yellow-legged hornet, Vespa velutina nigrithorax, in Europe. Apidologie 2014, 46, 130-132. [CrossRef]

75. Spradbery, J.P. Chap 6: Feeding and Foraging. In Wasps. An Account of the Biology and Natural History of Solitary and Social Wasps; Sidgwick \& Jackson: London, UK, 1973; pp. 128-157.

76. Villemant, C.; Zuccon, D.; Rome, Q.; Muller, F.; Poinar, G.O., Jr.; Justine, J.L. Des parasites peuvent-ils stopper l'invasion? Des nématodes mermithidés parasitent le frelon asiatique à pattes jaunes en France. Peer J. 2015, 947. [CrossRef]

77. Harris, R.; Harcourt, S.J.; Glare, T.R.; Rose, E.A.F.; Nelson, T.J. Susceptibility of Vespula vulgaris (Hymenoptera: Vespidae) to Generalist Entomopathogenic Fungi and their potential for wasp control. J. Invertebr. Pathol. 2000, 75, 251-258. [CrossRef]

78. Poidatz, J.; López Plantey, R.; Thiéry, D. Indigenous strains of Beauveria and Metharizium as potential biological control agents against the invasive hornet Vespa velutina. J. Invertebr. Pathol. 2018, 153, 180-185. [CrossRef]

79. Macià, F.X.; Menchetti, M.; Corbella, C.; Grajera, J.; Vila, R. Exploitation of the invasive Asian Hornet Vespa velutina by the European Honey Buzzard Pernis apivorus. Bird Study 2019, 66, 425-429. [CrossRef] 